\title{
Crown-Stump Diameter Model for Parkia biglobosa Benth. Species in Makurdi, Benue State, Nigeria
}

\author{
O. Chukwu*1, J.H. Dau ${ }^{2}$ and J.U. Ezenwenyi ${ }^{3}$ \\ ${ }^{* 1,3}$ Department of Forest Resources Management, University of Ibadan, Ibadan, Nigeria \\ ${ }^{2}$ Department of Forest Production and Products, University of Agriculture, Makurdi, Nigeria
}

Date Received: 09-03-2017

Date Accepted: 06-04-2017

\begin{abstract}
The crown of tree is the centre of physiological activity which gives an indication of the potential photosynthetic capacity on a tree. Though, its measurement remains a challenge in forest inventory task. The ability to predict crown diameter from stump diameter provides an effective technique of obtaining its estimate. This helps in detecting the excessive tree felling than actual requirements and wildlife suitability. The main objective of this study was to develop and test crown diameter prediction models for silvicultural management of naturally grown Parkia biglobosa within the University of Agriculture, Makurdi. Nine $100 \mathrm{~m}$ x $100 \mathrm{~m}$ temporary sample plots were established using simple random sampling method. Crown diameter and stump diameter were measured in all living $P$. biglobosa trees with stump diameter $\geq 10.0 \mathrm{~cm}$. Least square method was used to convert the counted stumps into harvested crown dimension. Three linear and three non-linear models using stump diameter as the exploratory variable were developed and evaluated using the adjusted coefficient of determination (Adj. $\mathrm{R}^{2}$ ), standard error of estimate (SEE), prediction error sum of squares (PRESS) and Akaike information criterion (AIC). The crown-stump diameter relationship was best described by the double logarithmic function with $A d j \cdot R^{2}=65.1 \%, S E E=0.1729, P R E S S=$ 262.9998and $A I C=717.56$. The result showed that Crown diameter estimation was feasible even when the only information available is stump diameter. The resulting equation was tested for validation with independent data obtained from additional plots and was found to be desirable for estimating the crown diameter for Parkia biglobosa in Makurdi, Benue State, Nigeria.
\end{abstract}

Keywords: Stump diameter, Crown diameter, Parkiabiglobosa, Double logarithmic, Economic trees

\section{Introduction}

Diameter at breast height (Dbh) and crown diameter are important tree characteristics. Some variables such as diameter at breast height and stump diameter are easy to measure with simple instruments and it is widely used in forest inventories. However, a number of studies have shown that other variables which are not so easily obtained are also good predictors of forest dynamics and they can improve the reliability of tools like growth and yield models. One of these variables is crown diameter, which has received increasing attention as a means to estimate tree growth (Bragg, 2001; Adesoye and Ezenwenyi, 2015).

The crown of tree is the centre of physiological activity, particularly gas exchange, which drives growth and development (Leites and Robinson, 2004). When natural or anthropogenic stresses impact a forest, the first signs of deterioration may be observed in the tree crowns. Thus, measurement of a tree crown is often used to assist in the quantification of tree growth (Kozlowski et al., 1991; Popoola and Adesoye, 2012; Adesoye and Ezenwenyi, 2015). Dubravac et al. (2009), stated that crown of tree is one of the most important elements of tree structure. Hence, tree crown diameter still

*Correspondence: onye20042000@yahoo.com

Tel: +2348032633835

ISSN 2235-9370 Print / ISSN 2235-9362 Online @2017 University of Sri Jayewardenepura 
remains one of the most difficult tasks in forest inventory. It is relevant in studies of stands growth, and the density of trees in a stand (Hemery et al., 2005). Despite the important of this tree part, little attention has been given on tree crown diameter in forest inventory and measurement.

Various reasons could necessitate the reconstruction of sizes of removed trees. These reasons include; reviewing harvesting practices, assessing damage due to catastrophic events, creating historical records of past management activities, and establishing loss due to timber trespass (CorralRivas et al., 2007; Westfall, 2010). Previous studies have shown that tree crown diameter (Cd) is well correlated with tree bole diameter (Kigomo, 1991; Gering and May, 1995; Kigomo, 1998; Lockhart et al., 2005; Hemery et al., 2005). In the same vein, stump diameter (Dst) is highly correlated with diameter at breast height (Dbh), and as such have being used in place of Dbh to predict most tree growth variable especially in the case of illegal logging (Osho, 1983; Westfall, 2010; Özçelík et al., 2010; Shamaki and Akindele, 2013).

Functions which predict crown diameter using other growth variables such as stump diameter are tools that can be used by forest managers to provide accurate and timely information on current growing stock since crown diameter models can predict growth and yield of the forest. Crown diameter models are needed for interpreting forest inventories of growing stock and for determining the cultural treatment to be employed. According to Sprinz and Burkhart (1987), the advantage of using crown characteristics as a basic modelling unit is the growth relationships that exist between the tree crowns and stem. Crown dimensions and development may be affected by spacing, stand density, or the cultural treatment carried out in the reserve such as thinning which also affect the stem. If the effects of cultural treatments on crown development are quantified, then it is possible to better understand and estimate treatment effects on stem and stand characteristics.

There is need to evolve an indirect method of predicting crown diameter (CD) of trees from stumps, which should be accurate and easily applicable. This can help in detecting the oversize markings and undersize recordings of trees and also excessive felling than actual requirements. This can be possible by using the regression and correlation studies between stump diameter as independent variable and crown diameter as dependent variable. The aim of this study was to develop a crown diameter prediction models for P. biglobosa grown within the University of Agriculture, Makurdi. The results served as tools in ascertaining stump diameter from aerial photographs and as an aid stand in structure determination and silvicultural practices.

\section{Material and Methods}

\subsection{Tree Species Description}

Parkia biglobosa is common around villages in the Savannah areas of West Africa where it is left standing when land is cleared or sometimes planted (Hutchinson and Dalziel, 1963). It is a dicotyledonous angiosperm, belonging to the family Fabaceae (Alabiet al., 2005). The plant is categorized under vascular plants; it is a deciduous perennial plant that grows up to between 7 and 20 meters height in some cases up to 30 meters (Ntui et al., 2012). The tree species commonly referred to aslocust beans, "Daddawa", "Ogiri" and "Iru" in Hausa, Igbo and Yoruba languages of Nigeria respectively, has several uses, including fodder, food, medicine, green manure, fuel wood, timber and economic purposes (Elly and Joseph, 2012). The cultivation of Parkia biglobosa can be seen as an important economic activity for many developing countries (Teklehaimanot, 2004). Hence, this species was selected for this present study based on its economic values to North and South-western parts of Nigeria. 


\subsection{Study Area}

This study was carried out in the University of Agriculture Makurdi, Benue State, Nigeria. It is located between longitudes $8^{\circ} 21^{\prime}$ to $9^{\circ} \mathrm{E}$ and latitude $7^{\circ} 21^{\prime}$ to $8^{\circ} \mathrm{N}$ in Benue State, within the southern Guinea savannah ecological zone of Nigeria and covers a total land area of $7,978 \mathrm{~km}^{2}$. The topography of the study area is characterized by gentle hills. The soil is mainly sandy-loamy; the climate is characterized by distinct rainy and dry seasons. The annual rainfall ranges between 1016 $\mathrm{mm}$ to $1524 \mathrm{~mm}$ spreading over May to October. The climate of the area is tropical sub-humid with high temperatures and high humidity; the average maximum and minimum daily temperature of $35^{\circ} \mathrm{C}$ and $21^{\circ} \mathrm{C}$ in wet season, and $38^{\circ} \mathrm{C}$ and $16^{\circ} \mathrm{C}$ in dry season. The study area is bounded at the NorthEast by Guma Local Government Area and by River Benue in the South (Gyang, 1997).

\subsection{Sampling Procedure and Data Collection}

This study was carried out in temporary sample plots of Parkia biglobosausing simple random sampling technique in Makurdi, Benue State, Nigeria. Nine (9) temporary sample plots (TSPs) of size $100 \mathrm{~m} \times 100 \mathrm{~m}$ were randomly selected within the study area. All living trees with stump diameter (Dst) $\geq 10.0 \mathrm{~cm}$ within each randomly selected sample plot were measured. The following tree growth variables measured were stump diameter $(\mathrm{cm})$, Diameter at breast height $(\mathrm{cm})$ and crown diameter. A total number of two hundred and sixty-five (265) trees were measured in all the nine selected plots.

\subsection{Crown diameter}

The tree crown diameter measurements were based on the assumption that the vertical projection of a tree crown is circular. Four radii were measured and in the direction forming equal angles (Krajicek et al., 1961; Foli et al., 2003; Zuhaidi, 2009). Tree crown diameter was measured by projecting the diameter of the crown with ranging poles on the ground at four different directions and taking the distance between the ranging poles using measuring tape calibrated in meters. The crown diameter was then obtained by taking the average of the two readings recorded from the four directions for each tree.

The average crown diameter $(\mathrm{Cd})$ was then calculated as such:

Where,

$$
C d=\sum \frac{r_{i}}{2}
$$

$C d=$ average crown diameter,

$r_{i}=$ projected crown radii measured on four axis

\subsection{Tree diameter}

Stump diameter (Dst) was measured for all the living tree individuals $\geq 10.0 \mathrm{~cm}$ at the height of $0.3 \mathrm{~m}$ and diameter at breast height was measured at the height of $1.3 \mathrm{~m}$. The point of the measurement was recorded from the uphill sides of the trees and on the inside of the lean for leaning trees. For trees with deformations at $0.3 \mathrm{~m}$, the measurement was made at the sound point on the stem above the abnormality. For buttressed trees, a point of measurement was selected approximately $0.5 \mathrm{~m}$ above the convergence of the buttress (Huschet al., 1982). Diameter measurements of trees were recorded using a metal metric diameter tape graduated in centimeters. During the measurement, loose bark, climbers and epiphytes were lifted above the measuring tape. 


\subsection{Crown Projection Area}

Based on the calculated or predicted Cd, the Crown Projection Area (CPA) can be calculated and expressed in ha (Krajicek et al., 1961):

$$
C P A=\frac{\pi C D^{2} / 10000}{4}
$$

Where,

$\mathrm{CD}=$ crown diameter $(\mathrm{m})$

$\pi=\mathrm{Pi}(3.146)$

\section{Data Analysis}

\subsection{Model description and fitting procedure}

The available fitting data consists of measurements taken from trees located within different selected plots. Least square method was used to fit data using the various candidate functions listed below. In this study, six crown-stump diameter equations were proposed as candidate models for the crown diameter prediction of $P$. biglobosain the study area. These equations are listed accordingly as follows: linear, single logarithm, double logarithm, Power, growth and exponential. The Candidate models are expressed as follows;

$$
\begin{aligned}
& C d=b_{0}+b_{1} D s t \\
& C d=b_{0}+b_{1} \ln D s t \\
& \ln C d=b_{0}+b_{1} \ln D s t \\
& C d=b_{0} D s t b_{1} \\
& C d=e^{\left(b_{0}+b_{1} D s t\right)} \\
& C d=b_{0} e^{\left(b_{1} D s t\right)}
\end{aligned}
$$

Where;

$\mathrm{Cd}=$ Crown diameter,

Dst $=$ Stump diameter, $\mathrm{b}_{0}$ and $\mathrm{b}_{1}=$ regression parameter

\subsection{Model Evaluation and Validation}

The evaluation of the candidate models was based on graphical and numerical analysis of the residuals which are; least values of the standard error of estimate (SEE), prediction error sum of squares (PRESS), Akaike information criterion (AIC) and adjusted coefficient of determination $\left(\right.$ Adj. $\left.\mathrm{R}^{2}\right)$. They are mathematically expressed as follows:

$$
\begin{aligned}
& \text { Adj. } R^{2}=1-\frac{\left(1-R^{2}\right)(n-1)}{n-p} \\
& \text { S.E.E. }=\sqrt{\frac{\sum\left(Y_{i}-\widehat{Y}_{i}\right)^{2}}{n-p}} \\
& \text { PRESS }=\sum_{i=1}^{n}\left(\left[Y_{i}-\right] \widehat{Y}_{(-i)}^{*}\right)^{2} \\
& \text { AIC }=N \ln (R S S)+2 p \\
& \text { Where; }
\end{aligned}
$$

$\bar{Y}_{i}=$ arithmetic mean of the observed value,

$Y_{i}=$ observed value of $\mathrm{Y}$ for observation $i$

$\hat{Y}_{i}=$ predicted value $i$,

$\hat{Y}_{(-i)}^{*}=$ predicted value of $\mathrm{Y}$ for observation $\mathrm{i}$ as calculated from a regression equation derived through fitting the p parameter model to data obtained by deleting observation $i$ from the original data set, 
$n=$ the total number of observations $Y_{i}$ (trees) used in fitting the model, $p=$ the number of model fixed parameters, $R S S=$ Residual sum of square.

The overall best candidate model was validated using an independent data of about one-third of the data used for the model calibration and fitting. The t-test for paired samples was adopted as the validation method in this study. In all statistical analyses, a confidence level of $p<0.05$ was used for statistical significance.

\section{Results}

\subsection{Summary Statistics for tree growth variables}

The data obtained from the field inventory were carefully organized and analysed in order to detect the underlying growth patterns. The data comprise of tree growth variables measured from nine sample plots of Parkia biglobosa stand in the University of Agriculture Makurdi, Benue State. A total of 265 trees were measured and summary statistics of the data used in this study are presented in Figures $(1-2)$ below. The mean values, standard deviation (SD) and standard error (SE) of crown diameter and stump diameter are displayed in the box plots below (Figures $1-2$ ). The distribution of stump diameter (Dst) ranged from 27.50 to $95.43 \mathrm{~cm}$ and crown diameter ranged from 2.90 to 11.55 m.

Table 1 shows the result of Pearson's product-moment correlation analysis between crown diameter (Cd), diameter at breast height (Dbh) and stump diameter (Dst). The result revealed that Dbh and Dst are highly and positively correlated $(\mathrm{r}=0.93)$. The result also shows that $\mathrm{Cd}$ is highly and positively correlated with Dst with $\mathrm{r}$ value of 0.84 . This implies that $\mathrm{Cd}$ increases with increase in Dst.

The graphical relation between the explanatory variable (Dst) versus response variable $(\mathrm{Cd})$ is shown in figure 3. The pattern of the scatter plot (graph) showed that crown diameter of Parkia biglobosa in the study area are essentially linearly related with stump diameter.

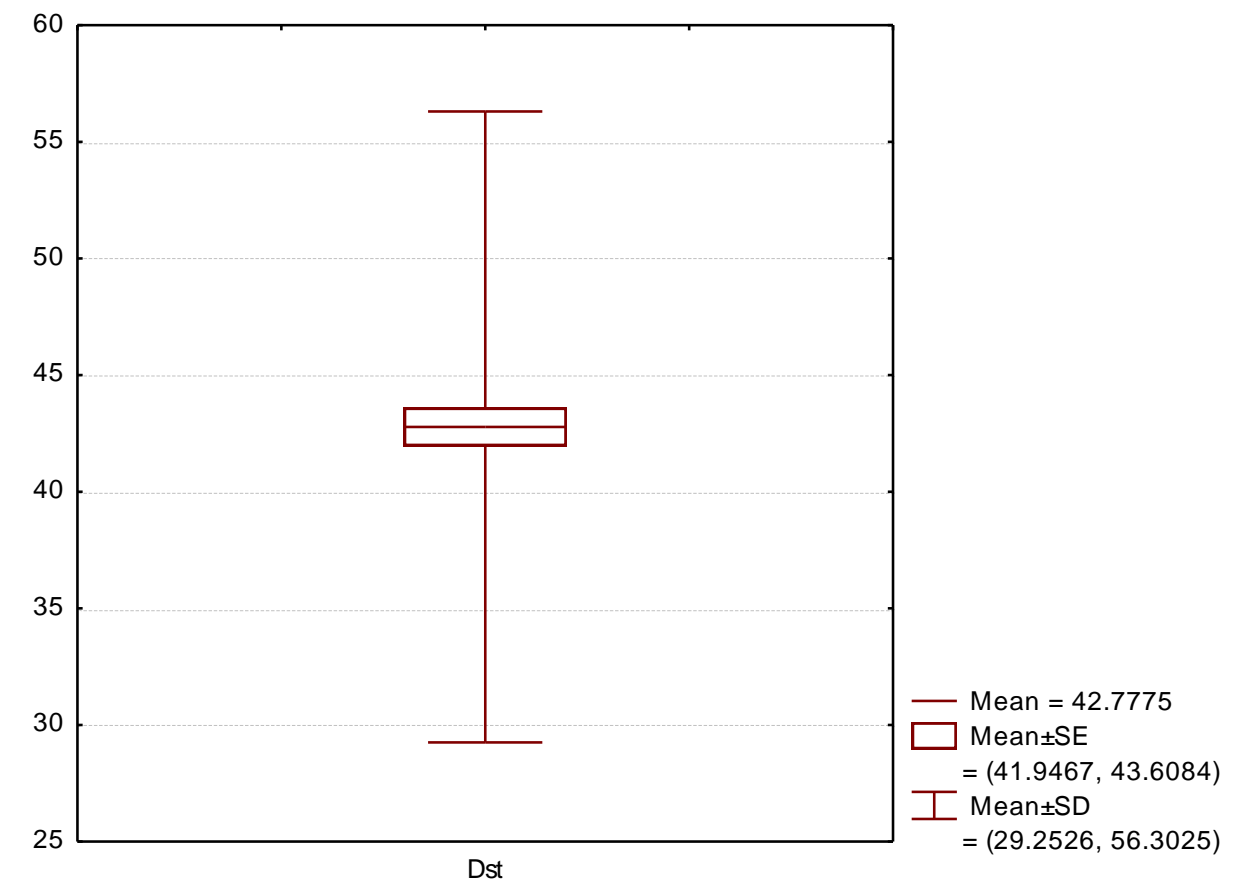

Figure 1: Box and whisker for summary statistics of tree stump diameter (Dst) in $\mathrm{cm}$. 


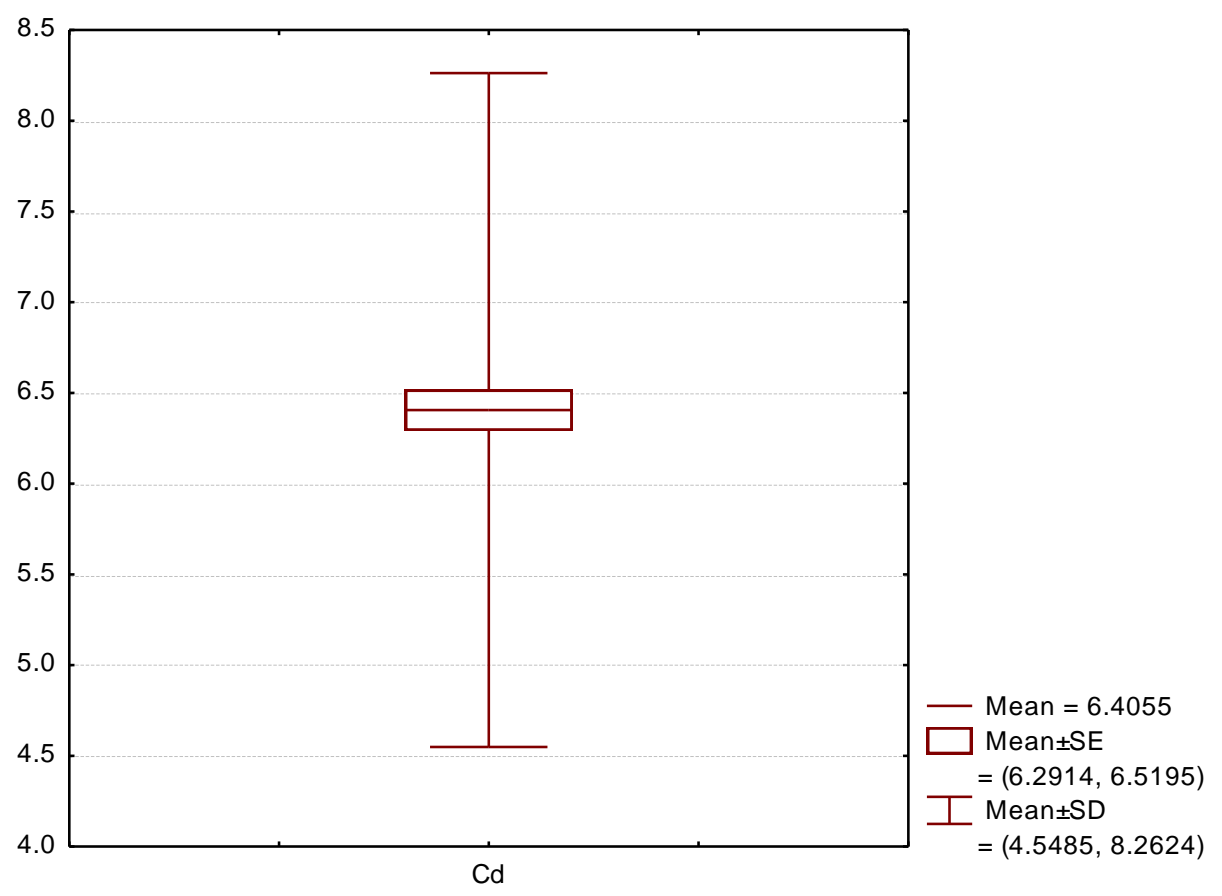

Figure 2: Box and whisker for summary statistics of tree crown diameter $(\mathrm{Cd})$ in $\mathrm{m}$.

Table 1: Correlation Analysis

\begin{tabular}{|c|c|c|c|c|}
\hline & Dst $(\mathrm{cm})$ & $\operatorname{Dbh}(\mathrm{cm})$ & $\mathrm{Cd}(\mathrm{m})$ & \\
\hline Dst $(\mathrm{cm})$ & 1 & & & \\
\hline Dbh $(\mathrm{cm})$ & $0.93 *$ & 1 & & \\
\hline $\mathrm{Cd}(\mathrm{m})$ & $0.84^{*}$ & $0.84^{*}$ & & 1 \\
\hline
\end{tabular}

* Correlation coefficient is significant at the 0.05 level $(2$ tailed $), \mathrm{N}=265, \mathrm{Cd}=$ Crown diameter $(\mathrm{m}), \mathrm{Dbh}=$ Diameter at breast height $(\mathrm{cm})$ and Dst $=$ Stump diameter $(\mathrm{cm})$

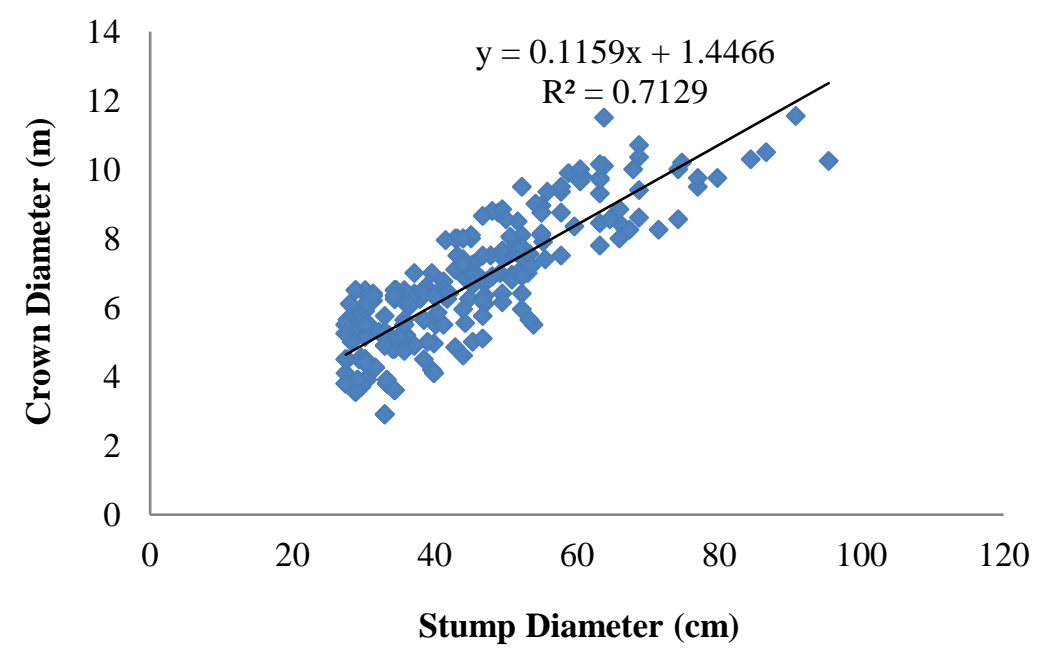

Figure 3: Relationship between Crown diameter and Stump diameter. 


\subsection{Crown Diameter Prediction Models}

The crown diameter models developed in this study was to estimate the present and future values of crown diameter at individual tree level for Parkia biglobosa within the University of Agriculture, Makurdi. The models were developed using individual tree stump diameter as independent variable and crown diameter as dependent variable. The models developed and tested (Equations 3-8) were in linear, single logarithmic, double logarithmic, power and exponential functions. All parameters were found to be significant at the 5\% level of probability. The models used for fitting data performed well and produced very similar results. On the basis of estimated $A d j . R^{2}$ values, $65.1 \%$ to $71.2 \%$ of the total variation in observed crown diameter values was explained by stump diameter in the six candidate models.

The individual tree models developed using stump diameter (Dst) as independent variable (Table 2) showed that power model has the highest value of $\operatorname{Adj}^{2} R^{2}(0.716)$ with SEE, PRESS and AIC values of $0.9897,0.9897,257.5322$ and 2482.37 respectively. This was followed by linear and single logarithmic models with the same values of Adj. $\mathrm{R}^{2}$ of 0.712 but with differences in the values of SEE, PRESS and AIC values (Table 2). Double logarithmic function (model 3) gave the least value of adj. $\mathrm{R}^{2}$ of 0.651 with SEE, PRESS and AIC values of 0.1729, 262.9998 and 717.56 correspondingly.

Figure 4 shows the graph of the residuals distribution against the predicted natural logarithm of crown diameter. The equation 5 seems to uphold constant error variance assumption.

\subsection{Model Validation}

Table 3 shows the result of the validation of the best model (equation 5). The validation test shows that observed value was not significantly different from the predicted value of natural logarithm of crown diameter at probability level of 0.05 .

Table 2: Examined Crown-Stump Diameter Models

\begin{tabular}{llllll}
\hline Model No & Function & \multicolumn{4}{c}{ Fit Statistics } \\
\cline { 3 - 6 } & & Adj.R & SEE & PRESS & AIC \\
\hline 1 & $C d=1.447+0.116 D s t$ & 0.712 & 0.9969 & 262.9999 & 1719.97 \\
2 & $C d=11.227+5.398 \ln D s t$ & 0.712 & 0.9960 & 263.0001 & 1720.16 \\
3 & $\ln C d=2.542+0.814 \ln D s t$ & 0.651 & 0.1729 & 262.9998 & 717.56 \\
4 & $C d=12.577 \times D s t^{0.785}$ & 0.716 & 0.9897 & 257.5322 & 2482.37 \\
5 & $C d=e^{(1.201+1.487 D s t)}$ & 0.672 & 1.0644 & 297.9509 & 2481.44 \\
& $C d=3.324 \times e^{(1.487 D s t)}$ & 0.672 & 1.0644 & 297.9509 & 2481.44 \\
\hline
\end{tabular}




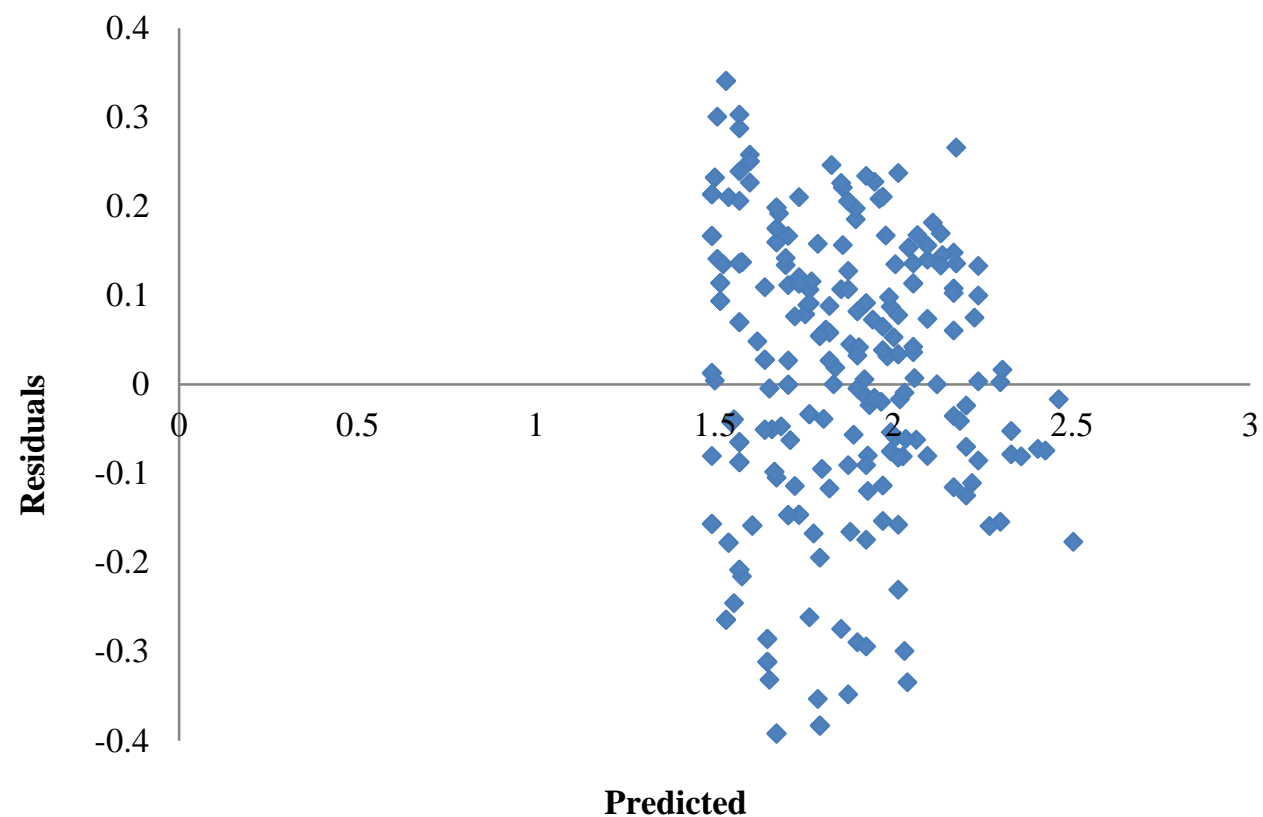

Figure 4: Residual distribution against $\ln \mathrm{Cd}$ using double logarithmic model (equation $5)$.

Table 3: Results of Validation of Model 3 using t test for Paired Sample

\begin{tabular}{lllllllllll}
\hline Variable & Mean & SD & $\begin{array}{l}\text { SE } \\
\text { Mean }\end{array}$ & N & Diff & T & Df & P & Remark \\
\hline Cd Observed & 6.5720 & 1.8220 & 0.1988 & & & & & & \\
Cd Predicted & 5.5533 & 0.2415 & 0.0264 & 84 & 0.0187 & 1.7414 & 83 & 0.3451 & ns \\
\hline
\end{tabular}

$\mathrm{SD}=$ standard deviation, Standard error, Diff $=$ hypothesized mean difference, $\mathrm{df}=$ degree of freedom, $\mathrm{p}=$ probability value, $\mathrm{ns}=$ not significant at 0.05 .

\section{Discussion}

In this study, information on the tree growth variables (Dst and Cd) was presented in Figures 1and 2. Before models development, correlation analysis was carried out to give an insight of the association between crown diameter and other tree growth variables. It was observed from the correlation matrix that crown diameter was highly correlated with stump diameter. That is, trees with larger diameter have wider crown diameters. This relationship is of adaptive significance to the trees because crown diameter contributes immensely to trees total weight. It was observed from graphical relationship that crown diameter showed a linear relationship with stump diameter. Avery and Burkhart (2002) stated that forest management decisions are predicated on information about current and future resource conditions.

However, in this study effort was directed towards obtaining crown diameter prediction models at individual tree base using stump diameter. Previous study by Shamaki and Akindele (2013) has proven that diameter at breast height (Dbh) and stump diameter (Dst) are highly correlated. Hence, to avoid co-linearity between the two growth variables (Dst and dbh) as indicated by Huang et al. (2003), only stump was selected as independent variable for developing crown diameter models. The principle of using stump diameter alone was to help forest managers obtain information on the original crown structure of a forest after exploitation either by legal or illegal activities within the forest. Estimating tree growth variables after exploitation can only be possibly done through the stumps (Osho, 1983; Shamaki and Akindele, 2013). 
The developed models using stump diameter as explanatory variable were in linear, single logarithmic, double logarithmic, power, and exponential functions form (Equations 3 - 8). The models used for fitting data performed well and produced very similar results. All parameters were found to be significant at the $5 \%$ level of probability.On the basis of estimated $A d j . R^{2}$ values; $65.1 \%$ to $71.2 \%$ of the total variation in observed crown diameter values was explained by stump diameter in the candidate models. The criteria adopted for ranking the models was through comparison of Adj. $\mathrm{R}^{2}$, SEE, PRESS and AIC which are standard ways of verifying models predictive ability as pointed out by Li et al. (2002), Huang et al. (2003), Shamaki and Akindele (2013) and Adesoye and Ezenwenyi (2015).

From the results of model evaluation criteria, out of the six candidate models showed that equation 5 (double logarithmic function) ranked the first, with the least values of; SEE, PRESS and AIC. Comparable results were reported by Shamaki and Akindele (2013) as in the case of Merchantable volume and Stump diameter relationship and Adesoye and Ezenwenyi (2015); using Dbh to predict crown diameter. This reveals that stump diameter can play a similar role to Dbh as a good predictor of Crown diameter.

This result is not similar to the findings of Avsar and Ayyildiz (2005) who observed that crown diameter-Dbh relationships can be described by power model. Though, his report was on crown diameter and Dbh which can be used interchangeably with stump diameter. In this study Power model was found to be inappropriate. The double logarithmic function (model 3) was chosen as the best fitted model, although it has the least value of Adjusted $\mathrm{R}^{2}$. However, other functions (including Power model) had higher value of Adjusted $\mathrm{R}^{2}$ but they also displayed relatively higher values of estimation errors (SEE, PRESS and AIC) which are not good predictor of best models. Therefore, all the evaluation criteria (Adj. $\mathrm{R}^{2}$, SEE, PRESS and AIC) were considered in ranking and subsequent selection of the models. The higher the Adjusted $\mathrm{R}^{2}$ values the better and the lower the SEE, PRESS and AIC the better the model. The efficiency of this procedure was confirmed by Akindele (1985) and Odunlami (1992).

Hence, additional data from independent plots were used to validate the model. The paired ttest was used to test for significance between predicted and the observed crown diameters. The result showed a non-significant difference. This indicates that the developed crown-stump diameter equation is valid for estimation of $P$. biglobosa stands in Makurdi, Benue State. Furthermore, Figure 4 shows the distribution of residuals against the predicted natural logarithm of crown diameter and constant error variance assumption appears to be upheld by this double logarithm model (equation 5).

\section{Conclusions}

Predicting tree growth characteristics for stump diameter can aid the reconstruction of sizes of removed trees. These includes; reviewing harvesting practices, assessing damage due to catastrophic events, creating historical records of past management activities, and establishing loss due to timber trespass. Hence, stump diameter was therefore, used as the only independent variable owing to its strong correlation with Dbh as asserted by this study. Thus, both Dbh and Dst can be used interchangeably. This study further concluded that, the crown diameter can be more accurately and precisely predicted from Stump diameter using the double logarithmic function (equation 5). This model is therefore, recommended for the forest managers and the management of the University of Agriculture Makurdi as a research tool and a good estimator of crown diameter in an event of both legal and illegal felling.

It should be noted that the models developed by this study were based on data collected in University of Agriculture Makurdi, Benue State catchment region and covered a limited range of 
stump and crown diameters. The models should therefore, be used with caution outside this region. Further studies need to be done to test applicability of these models across similar ecological zones and to relate the growth rates/patterns in both Stump and crown diameters of open grown tree species to the fitted models.

\section{Reference}

Adesoye, P.O. and Ezenwenyi, J.U. 2015. Crown Diameter Prediction Models for TectonaGrandisLinn.FinOmo Forest Reserve, Nigeria, Journal of Forestry Research and Management. Vol.11, 72-87; 2014. ISSN: 0189-8418

Akindele, S.O., 1985. The development of various linear volume equations for Teak in Gambari forest reserve. Unpublished B.Sc. project. University of Ibadan, Nigeria. 72p.

Akindele, S.O., 2003. Volume Prediction from Stump Diameters of Gmelinaarborea(Roxb) trees in Akure forest reserve, Nigeria. Nigerian Journal of Forestry, Vol. 33 (2): 116 - 123.

Alabi, D.A., Akinsulire, O.R. and Sanyaolu, M.A., 2005. African Journal of Biotechnol; Vol. 4; Pp. 812-815.

Avsar M. D and V. Ayyildiz (2005): The Relationships between Diameter at breastheight, Tree Height and Crown Diameter in Lebanon Cedar(CedruslibaniA.Rich.) of the Yavsan Mountain, Kahramanmaras, Turkey.Pakistan Journal of Biological Sciences 8 (9), 1228-1232p.

Corral-Rivas, J.J., Barrio-Anta, M., Aguirre-Calderon, O.A. and Dieguez-Aranda. U., 2007. Use of stump diameter to estimate diameter at breastheight and tree volume for major pine species in El Salto Durango (Mexico). Forestry80:29-40.

Dubravac, T., Dekanic J., Vrbek B., Matosevic, D., Roth V., Jakovljevic, T. and Zlatanov, T., 2009. Crown volume in forest stands of pedunculate oak and common hornbeam. PeriodicumBiologorum111(4), 479-485.

Elly, N.S. and Joseph, C., 2012. ParkiaBiglobosa: A Pot ential Multipurpose Fodder Tree Legume in West Africa. International Tree Crops Journal; Volume 7, Issue 1992; Published online: 05 Apr 2012; DOI: 10.1080/01435698.1992.9752911; pages 113-139

Foli, E.G., Alder, D., Miller, H.G. and Swaine, M.D., 2003. Modeling Growing Space Requirements for some Tropical Forest Tree Species; Forest Ecology and Management 173 (2003); pp. 7988

Gering, L.R. and May, D.M., 1995. The relationship of diameter at breast height and crown diameter for four species groups in Hardin County, Tennessee. South. Journal of Applied Forestry 19:177-181.

Gyang, E.O., 1997. Students Information Handbook (1996-1998). University of Agriculture, Makurdi. P. 1-3.

Hemery, G.E., Savill P.S., and Pryor S.N., 2005. Applications of the crown diameter stem diameter relationship for different species of broadleaved trees. Forest Ecol. Manage., 215(3): 285-294.

Husch B., Beers, T.W. and Kershaw Jr. J.A., 2003. Forest Mensuration4th edition. New Jersey: John Wiley and Sons Inc. 443pp.

Husch, B., Miller C.I. and Beers, T.W., 1982. Forest Measurement. John Wiley \& Sons, New York, USA.

Hutchinson, J., and Dalziel, J.M., 1963. Flora of West Tropical Africa. Crown Agents, London, 6 vols.

Kigomo, B.N., 1991. Crown and bole diameter relationship in Brachyleanahuillensisand its application to silvicultural interventions. E. Afr. Agric. Forest. J., 57(1): 67-73.

Kigomo, B.N., 1998. Morphological and growth characteristics in Brachyleanahuillensis(Muhugu); some management considerations. Kenya J. Sci. (Series B), 11(1-2): 11-20.

Kozlowski T., Kramer P., Pallardy S., 1991. The Physiological Ecology of Woody Plants. Academic Press, New York. 
Krajicek J.E., Brinkman, K.A and Gringrich S.F., 1961. Crown competition a measure of density. Forest Science 7: 35-42.

Li B., Morris, J. and Martin, E.B., 2002. Model selection for partial least squares regression, Chemometrics and Intelligent Laboratory Systems 64, 79- 89

Lockhart, B.R., Robert, C., Weih J.R. and Keith, M.S., 2005. Crown radius and diameter at breast height relationships for six bottomland hardwood species. J. Arkansas Acad. Sci., 59: 110-115.

Ntui, V.O., Uyoh, E.A., Urua, I.S., Ogbu, U., and Okpako, E.C., 2012. Regeneration of ParkiabiglobosaBenth.: An important tree species of Africa. Journal of Microbiology and Biotechnology Research, 2(1), 169-177; the Scholar's Research Library database; ISSN: 2231 3168.

Odunlami B.A., 1992. Development of volume equations for Gmelinaarboreaplantation in Oluwa Forest Reserve. Unpublished B. Agric (Teh) project FUT Akure. 66p

Osho, J.S.A., 1983. Volume Prediction from Stump Diameter for Teak (TectonagrandisL.f.) in Onigambari Forest Reserve. Nigerian Journal of Forestry 13 (1\&2): 53-56.

Özçelík R., Brooks J.R., Diamantopoulou, M.J. and Wiant-Jr, H.V., 2010. Estimating breast heght diameter and volume from stump diameter for three economically important species in Turkey, Scandinavian Journal of Forest Research, Vol. 25,Iss. 1, http://dx.doi.org/10.1080/02827580903280053

PopoolaF.S.andAdesoye P.O., 2012. Crown Ratio Models for Tectonagrandis(Linn. f) stands in Osho Forest Reserve, Oyo State, Nigeria Journal of Forest Science, ISSN 2287-2396, Vol. 28, No. 2, pp. 63-67,

Shamaki, S.B. and Akindele, S.O., 2013. Volume estimation models from stump diameter for teak (TectonagrandisLinn f.) plantation in Nimbia forest reserve, Nigeria, Journal of Environmental Science and Water Resources, ISSN 2277 0704, Vol. 2(3), pp. 089 - 094

Teklehaimanot, Z. 2004. Exploiting the potential of indigenous agroforestry trees: Parkiabiglobosa and Vitellariaparadoxa in sub-Saharan Africa.Agroforestry Systems, 61, 207-220

Westfall, J.A., 2010. New Models for Predicting Diameter at Breast Height from Stump Dimensions, North. J. Appl. For. 27(1)

Zuhaidi, Y.A., 2009. Local Growth Model in Modeling the Crown Diameter of plantation-Grown Dryobalanops aromatic; Journal of Tropical Forest Science 21(1); Pp.66-71. 